\title{
Light-induced Encystment of Blastocladiella emersonii Zoospores
}

\author{
By E. C. CANTINO AND L. C. TRUESDELL \\ Department of Botany and Plant Pathology, Michigan State University, \\ East Lansing, Michigan, 48823 U.S.A.
}

(Accepted for publication 2I August 1971)

\begin{abstract}
SUMMARY
A low proportion of zoospores from dark-grown plants of Blastocladiella emersonii encyst if the suspension of zoospores is maintained in darkness, but visible light causes increased encystment. A lag in the response to light is eliminated by incubating spores in darkness prior to exposure. Light-induced encystment is insensitive to cycloheximide, but ceases when illumination ceases. Light has no effect on encystment of zoospores derived from light-grown plants; these will encyst even if kept in darkness.
\end{abstract}

\section{INTRODUCTION}

Light-stimulated growth, when defined in terms of increasing weight, is rare (Carlile, 1965, 1970) among fungi. The most adequately documented instances occur in aquatic fungi, the fresh-water Chytridiomycete Blastocladiella emersonii (Cantino \& Horenstein, 1956 a) and the chytrid-like marine Oomycete, Thraustochytrium roseum (Goldstein, 1963). With B. emersonii, visible light has a manifold effect (Cantino, 1965) upon growing thalli, and results in changes in dry weight, pools of small and large molecules (including a cytochrome- $b$ type haemoprotein), enzyme activities, uptake of $\mathrm{CO}_{2} / \mathrm{HCO}_{3}{ }^{-}$and'glycine, nuclear reproduction, exponential growth rate, and generation time. Some of these phenomena may involve light-stimulated metabolism of $\alpha$-ketoglutarate via isocitrate to succinate and glyoxylate.

We report here that white light also affects the zoospore, the non-growing stage in this organism's life-cycle, by inducing encystment. This process involves a complex of very rapid, interrelated, structural and functional transformations (Caninto, Truesdell \& Shaw, 1968; Soll, Bromberg \& Sonneborn, 1969; Truesdell \& Cantino, 1970, 1971), and should be useful for studying cellular differentiation apparently unaccompanied by protein synthesis (Lovett, 1968; Soll \& Sonneborn, 197I).

\section{METHODS}

The wild-type Blastocladiella emersonii was a strain continuously subcultured from the original isolate (Cantino \& Hyatt, 1953). Zoospores were produced by flooding singlegeneration OC (ordinary colourless) plants grown in darkness at $24^{\circ}$ on Difco 'Cantino PYG Agar'. After 15 min. the spore suspension was decanted, passed through filter paper, and used immediately. Population densities were measured by fixing zoospores in $5 \%(\mathrm{v} / \mathrm{v})$ glutaraldehyde and counting in a Speirs-Levy Eosinophil chamber. Encystment was studied by putting spore suspensions in $50 \mathrm{ml}$. Erlenmeyer flasks shaken at 76 oscillations/min. at $22^{\circ}$ in a Warburg bath (Precision Scientific), and either illuminated from below with a built-in incandescent light bank, $\left(3200 \mu \mathrm{W} / \mathrm{cm} .^{2}\right.$ at bottom of flasks) or kept dark with 
black paint or aluminium foil. Samples were removed at intervals, fixed as above, and scored for percent encystment. The effect of light intensity upon encystment was studied with $50 \mathrm{ml}$. flasks coated with various thicknesses of silver by the Rochelle Salts method (Hodgman, 1952-3). Their transmission, ranging from about 3\% to $100 \%$, was determined with an incandescent lamp and a Weston electric light meter. The transmission of colour filters (Edmund Scientific) was determined with a Beckman DU spectrophotometer and Gilford attachments.
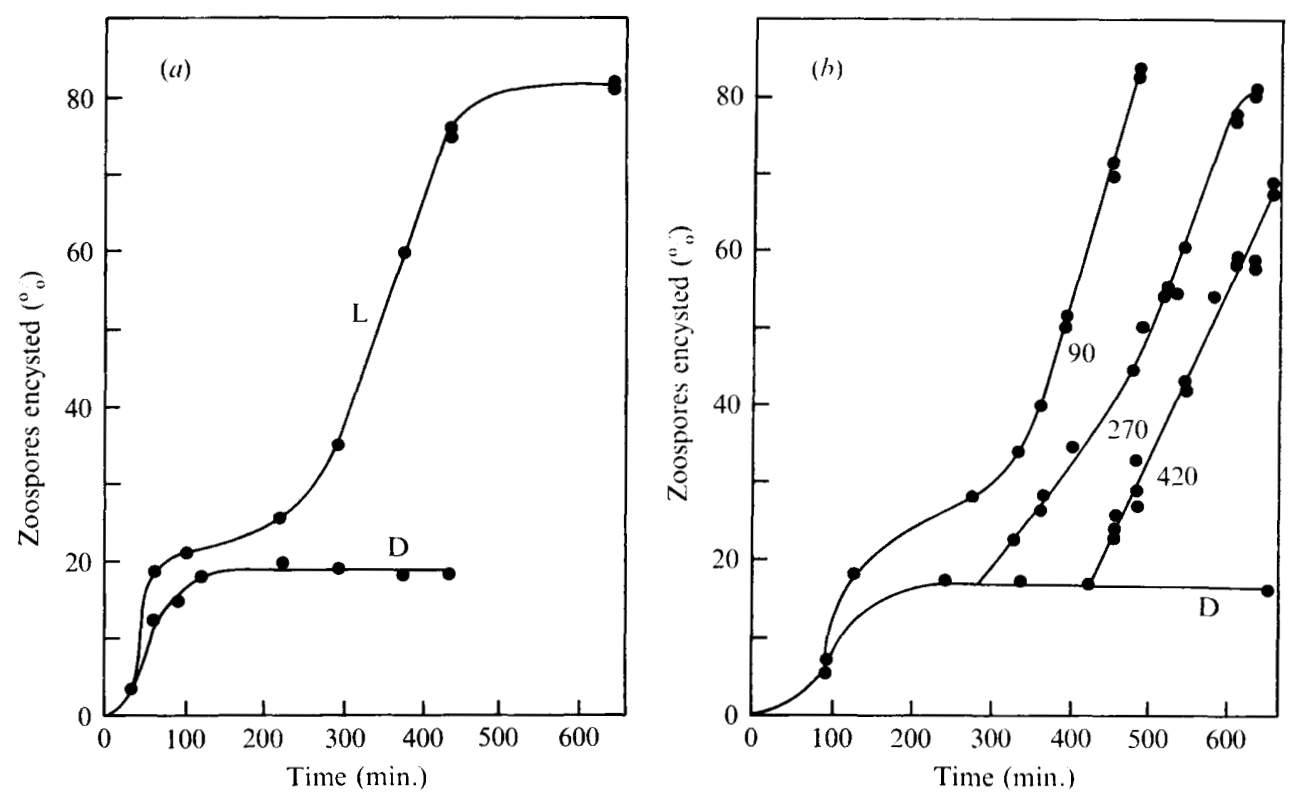

Fig. I. Effect of light $\left(3200 \mu \mathrm{W} / \mathrm{cm}^{2}\right)$ on encystment of zoospores. (a) Suspensions $\left(8.5 \times 10^{5}\right.$ spores $\mathrm{mi}$.) exposed continuously to light, L, and darkness, D. (b) Suspensions $\left(5.4 \times 10^{5}\right.$ spores $/ \mathrm{ml}$.) maintained in continuous darkness, $\mathrm{D}$, or transferred from darkness to light after 90,270 , and $420 \mathrm{~min}$. respectively.

\section{RESULTS AND DISCUSSION}

When freshly harvested and filtered zoospores from dark-grown plants were incubated in the dark, encystment of the population commenced but quickly levelled off (Fig. I $a$ ). When a sample of the same suspension was illuminated, further encystment occurred, but only after a lag.

If spores were incubated in the dark for $90 \mathrm{~min}$. before they were illuminated, encystment was stimulated by light (Fig. I $b$ ), but the initial lag period was shortened. When the spore population being incubated in the dark was left (e.g. for 270 or $420 \mathrm{~min}$.) to reach its encystment plateau before it was illuminated, the lag period preceding light-induced encystment was further reduced or entirely eliminated. In a previous study (Truesdell \& Cantino, I97I) with all three encystment inducers used (low temperatures, sulphonic acid dyes, and $\mathrm{KCl}$ ) the mean time of encystment for a spore population was always very much lower than it is for light-induced encystment. As shown above, the length of the dark period preceding illumination of a spore population was inversely related to the length of the lag period at the beginning of encystment and therefore to the mean time of encystment. These results are consistent with the possibility that a swimming spore derived from dark- 
grown plants must be altered in some way before it can encyst in response to light; preliminary evidence not reported here suggests that its DNA-containing $\gamma$-particles (Myers \& Cantino, 1971) may be involved.

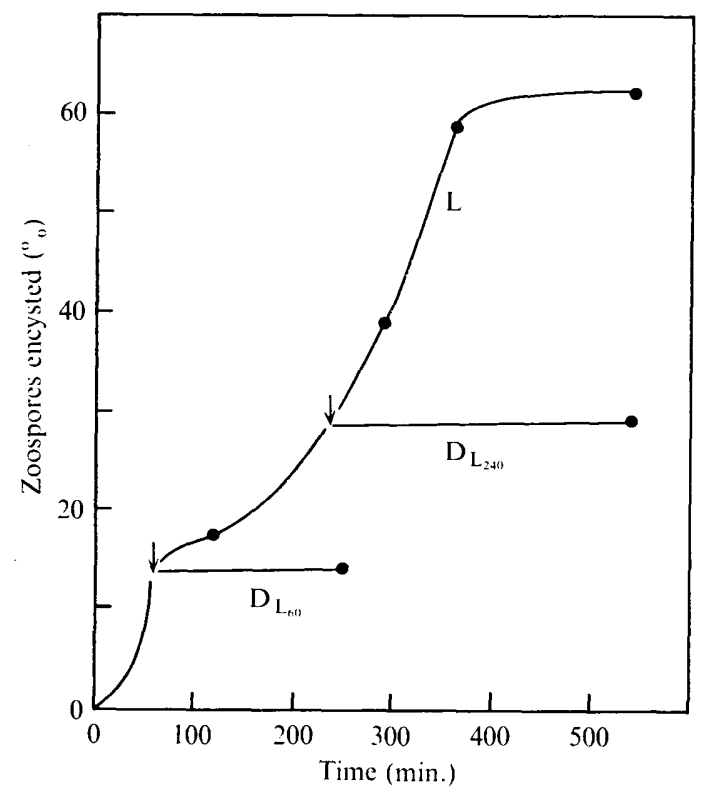

Fig. 2. Effect on encystment of transferring zoospores to darkness after exposure to light (3200 $\mu \mathrm{W}$ ) $\left.\mathrm{cm} .{ }^{2}\right)$. Suspensions $\left(\mathrm{I} \cdot 2 \times 10^{6}\right.$ spores $/ \mathrm{ml}$.) either left in light, $\mathrm{L}$, or transferred to darkness at 60 or $240 \mathrm{~min}$. Arrows indicate time of transfer.

Table r. Encystment maxima in darkness and white light $\left(3200 \mu \mathrm{W} / \mathrm{cm} .{ }^{2}\right)$ at various population densities

\section{Population density}

(spores $/ \mathrm{ml}$.)

$2.8 \times 10^{6}$
$2.1 \times 10^{6}$
$1.9 \times 10^{6}$
$1.7 \times 10^{6}$
$1.6 \times 10^{6}$
$1.3 \times 10^{6}$
$1.2 \times 10^{6}$
$1.1 \times 10^{6}$
$9.2 \times 10^{5}$
$8.5 \times 10^{5}$
$8.1 \times 10^{5}$
$7.2 \times 10^{5}$
$5.3 \times 10^{5}$
$5.0 \times 10^{5}$
$3.5 \times 10^{5}$
$2.8 \times 10^{5}$
Maximum encystment (\%)

$\begin{array}{rc}\text { Darkness } & \text { Light } \\ 28 & 50 \\ <5 & 51 \\ 19 & 52 \\ 13 & 42 \\ 6 & 32 \\ 23 & 73 \\ 9 & 62 \\ 8 & 65 \\ 10 & 84 \\ 18 & 82 \\ 20 & 70 \\ <5 & 93 \\ 10 & 88 \\ 5 & 86 \\ >90 & >90 \\ >75 & >90\end{array}$

With suspensions of above $10^{6}$ spores $/ \mathrm{ml}$. the maximum encystment induced by light seldom reached $70 \%$ (Table $\mathrm{I}$ ). In the range $5 \times 10^{5}$ to $10^{6}$ spores $/ \mathrm{ml}$., encystment in light was usually over $80 \%$, while in the dark it was generally under $20 \%$. At population densities 
below $5 \times 10^{5}$ spores $/ \mathrm{ml}$, encystment in the dark approached the high level obtained in light, hence a light effect was not observed. Population density was therefore a critical factor for encystment in the dark; if this relationship was a consequence of 'self inhibition' (Truesdell \& Cantino, I97I), visible light may have been functioning, in part at least, by overcoming its influence. It may be significant that in the media used by Soll \& Sonneborn (1969), not tested in the present study, germination synchrony was independent of spore concentration up to $4.2 \times 10^{5}$ cells $/ \mathrm{ml}$, whereas above $5.9 \times 10^{5}$ cells $/ \mathrm{ml}$., population density exerted inhibitory effects.

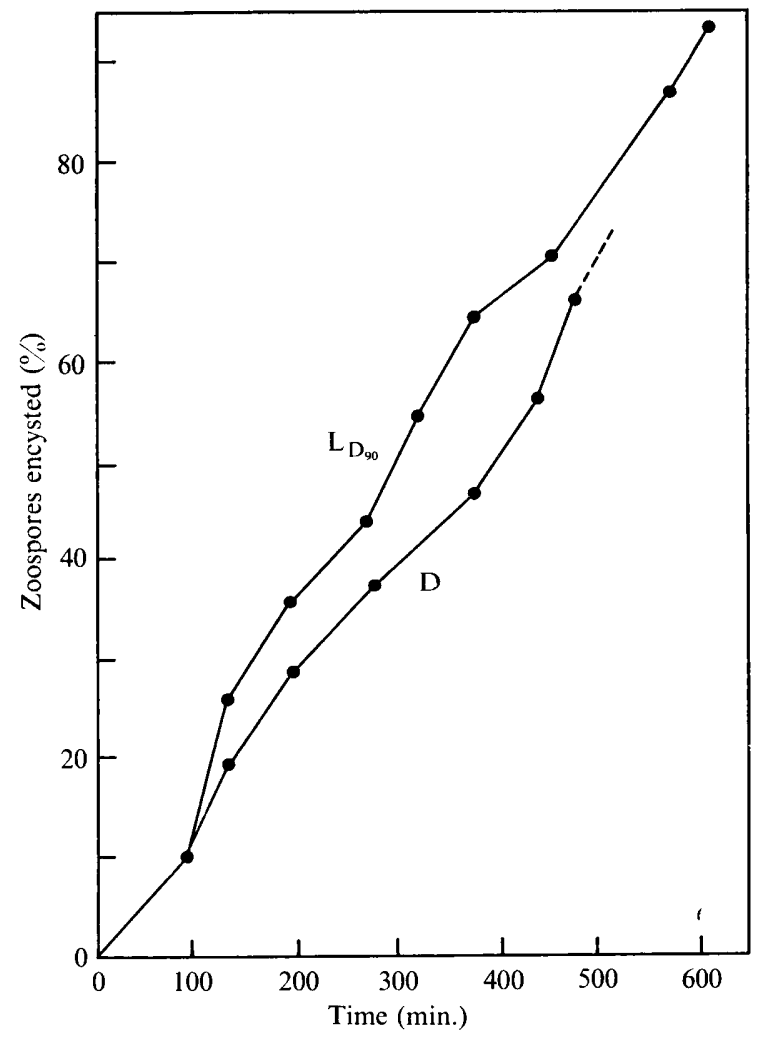

Fig. 3. Effect of growing parental OC (ordinary colourless) plants in light $\left(250 \mu \mathrm{W} / \mathrm{cm}^{2}, 24^{\circ}\right)$ on the encystment capacity of the zoospore suspension $\left(5.0 \times 10^{5}\right.$ spores $/ \mathrm{ml}$.) produced by them. The suspension was either maintained in darkness, D, or transferred to light after $90 \mathrm{~min}$., $\mathbf{L}$.

Light-induced encystment ceased abruptly when spores were transferred to darkness (Fig. 2). Attempts were made with filters to ascertain which regions of the visible spectrum were the most effective for inducing encystment. Preliminary results suggested that blue light (400 to $500 \mathrm{~nm}$.) was effective, but other wavelengths also seemed to play a role.

Concentrations of cycloheximide which inhibit growth of OC plants (Cantino \& Hyatt, 1953), young germlings (Matsumae \& Cantino, 197I) and spore germination (Lovett, I968; Soll \& Sonneborn, 197I) did not inhibit encystment (Lovett, I968; Soll \& Sonneborn, 1971). Whether cycloheximide could influence light induction of encystment was examined. A spore suspension $\left(6 \cdot 75 \times 10^{5}\right.$ spores $/ \mathrm{ml}$.) was incubated in the dark at $22^{\circ}$ for $90 \mathrm{~min}$. with $0.25 \mu \mathrm{g}$. cycloheximide/ml.; another suspension without cycloheximide was set up 
simultaneously. Half the suspension containing cycloheximide was then exposed to $3200 \mu \mathrm{W} /$ $\mathrm{cm} .^{2}$ of light and half was kept dark. The suspension without cycloheximide was then tested for the effect of cycloheximide (at two concentrations: $0.25 \mu \mathrm{g} . / \mathrm{ml}$. and $25.0 \mu \mathrm{g} . / \mathrm{ml}$.) upon light-induced encystment. In no instance was light-induced encystment affected by the presence of cycloheximide.

When OC plants were grown under $250 \mu \mathrm{W} / \mathrm{cm} .{ }^{2}$ of 'cool white' fluorescent light instead of darkness, and the zoospores derived therefrom tested as above, the difference in response of spores to light and darkness disappeared (Fig. 3). There is already ample evidence that the prior history of parental plants from which zoospores are derived may affect the $\gamma$-particles in a spore and alter the cell's composition or eventual behaviour (Cantino \& Hyatt, 1953; Cantino \& Horenstein, 1956b; Cantino, 1969; Matsumae, Myers \& Cantino, 1970). It is now shown that the lighting conditions imposed upon an OC plant can also influence the spores eventually derived from it, enabling them to encyst in total darkness.

This investigation was supported by general research grant A Ior568-I5 to E.C.C. from the National Institutes of Health.

\section{REFERENCES}

Cantino, E. C. (1965). Intracellular distribution of ${ }^{14} \mathrm{C}$ during sporogenesis in Blastocladiella emersonii. Effect of light on hemoprotein. Archiv für Mikrobiologie 5I, 42-59.

CANTINo, E. C. (1969). Physiological age and germinability of resistant sporangia of Blastocladiella emersonii. Transactions of the British Mycological Society 53, 463-495.

Cantino, E. C. \& Horenstein, E. A. (1956a). The stimulatory effect of light upon growth and $\mathrm{CO}_{2}$ fixation in Blastocladiella. I. The S.K.I. cycle. Mycologia 48, 777-799.

Cantino, E. C. \& Horenstein, E. A. (1956b). Gamma and the cytoplasmic control of differentiation in Blastocladiella. Mycologia 48, 443-446.

Cantino, E. C. \& HyatT, M. T. (1953). Phenotypic 'sex' determination in the life history of a new species of Blastocladiella, B. emersonii. Antonie van Leeuwenhoek Journal of Microbiology and Serology 19, 25-70.

Cantino, E. C., Truesdell, L. C. \& Shaw, D. S. (1968). Life history of the motile spore of Blastocladiella emersonii: a study in cell differentiation. Journal of the Elisha Mitchell Scientific Society 84, 125-146.

CarliLe, M. J. (1965). The photobiology of fungi. Annual Review of Plant Physiology 16, 175-202.

CARLILE, M. J. (1970). The photoresponses of fungi. In Photobiology of Micro-organisms. Edited by P. Halldal. New York: Wiley.

Goldstein, S. (1963). Studies of a new species of Thraustochytrium that displays light stimulated growth. Mycologia 55, 799-8II.

Hodgman, C. D. (1952-3). In Handbook of Chemistry and Physics, 34th edn., pp. 2777, 2785. Cleveland: Chemical Rubber Publishing Company.

LOVETT, J. S. (1968). Reactivation of ribonucleic acid and protein synthesis during germination of Blastocladiella zoospores and the role of the ribosomal nuclear cap. Journal of Bacteriology 96, 962-969.

Matsumae, A. \& CANTINo, E. C. (1971). Sensitivity of the spores of Blastocladiella emersonii and related fungi to antibiotics and some other drugs. The Journal of Antibiotics 24, 77-84.

Matsumae, A., Myers, R. B. \& Cantino, E. C. (1970). Comparative numbers of $\gamma$ particles in the flagellate cells of various species and mutants of Blastocladiella. Journal of General and Applied Microbiology, Tokyo 16, 443-453.

MYERS, R. B. \& CANTINO, E. C. (1971). DNA profile of the spore of Blastocladiella emersonii: evidence for $\gamma$-particle DNA. Archiv für Mikrobiologie 78, 252-267.

Soll, D. R., Bromberg, R. \& SONNEBorn, D. R. (I969). Zoospore germination in the water mold Blastocladiella emersonii. I. Measurement of germination and sequence of subcellular morphological changes. Developmental Biology 20, 183-217.

SOLL, D. R. \& SONNEBORN, D. R. (1969). Zoospore germination in the water mold, Blastocladiella emersonii. II. Influence of cellular and environmental variables on germination. Developmental Biology 20, 21 8-235. 
SOLL, D. R. \& SONNEBORN, D. R. (1971). Zoospore germination in Blastocladiella emersonii: cell differentia tion without protein synthesis? Proceedings of the National Academy of Sciences (U.S.A.) 68, 459-463.

Truesdell, L. C. \& CANTINo, E. C. (1970). Decay of $\gamma$-particles in germinating zoospores of Blastocladiella emersonii. Archiv für Mikrobiologie 70, 378-392.

TRUesdell, L. C. \& Cantino, E. C. (197I). The induction and early events of germination in the zoospore of Blastocladiella emersonii. In Current Topics in Developmental Biology, vol. 6. Edited by A. Monroy and A. A. Moscona. New York: Academic Press. (In the Press.) 